\title{
CHAYANOV'S SYNDROME AS FACED BY 'BAP' AGRIBUSINESS CORPORATION AND THE PEASANT COMMUNITIES LIVING IN AND NEARBY THE FORESTRY ESTATE CONCESSION
}

\author{
Sitepu Melva Fatika*, Sjarkowi Fachrurrozie, Yunita, Sari Serly Novita \\ Department of Agribusiness, University of Sriwijaya, Indonesia \\ *E-mail: melvatepu@gmail.com
}

\begin{abstract}
The survival of the fittest apparently applies in stages of agribusiness development. What had become concern of Chayanov during pre-communist era in Rusia as being highlighted by $D$. Thorner (1966) for its relevance in the world of today, it has also become serious matter within economic life of modern Indonesia. The same concern given by the Government of Indonesia (GOI) has been clearly implied by the enactment of the Act \#23/1997 and Act \#25/2007 coined with Act \#40/2007, which have to be responded by every large scale company. Among others is PT-BAP, an industrial forestry company established in 2004 acting as supplier to pulp \& paper company that exist already in Sumatra but lack of raw material. This paper is based on a research work in 2017 that was aimed at examining the effectiveness of GOI policy on mandatory CSR viewed from the stand point of large scale company that gave response to the regulation by allocating fund for empowering people living in the surrounding. There were 3-objectives of the study: 1) How successful was the CSR program while facing which policy constraints and being supported by which conducive determining factors?; 2) What kind of benefits and how much financial gain particularly that the CSR could generate annually for the peasant community?; 3) What potential problems that might lead to which social conflict, should the CSR program become actually failed or non-existence? The research findings revealed that the CSR program launched by PT-BAP has so far been warmly accepted by the targeted people although not much significant achievement in terms of additional income that could be obtained by them each year since 2015. Several technical constraints and social hindrances existed, against which some strategic improvement in extension service and innovative business process must be introduced. Otherwise, the so called social entropy (psychological, ecological, economic and cultural entropies) would sooner or later bring social disputes to the company causing socioanthropological disturbance to the industrial forestry agribusiness. Serious attention must be given in order to avoid Chayanov syndrome.
\end{abstract}

\section{KEY WORDS}

Chayanov syndrome, socio-entropy, forestry, agribusiness.

PT-BAP (Bumi Andalas Permai corporation) is an industrial forestry company that obtained investment permit for growing Acacia $s p$ \& Eucaliptus $s p$ on a large size concession of about 133.441 HAs located near the strait of Bangka in the eastern part of South Sumatra Province, Indonesia. It is an agribusiness company specially designed to provide a pulp industry in Sumatra with additional raw materials. The GOI has got very strong commitment to support the company for its sustainability, as the value of national export of pulp and paper products alone grew in total at a fantastic rate, $17 \%$ in 2015 . Surely, successful business activities of a company such as PT-BAP could give significant economic support to the country's fundamental economy.

However, when it comes to the issue of potential land disputes, it is factual that even in rural areas throughout the country nowadays there is high population density which requires more land for occupation and source of livelihood. Hence, large scale allocation of land resource for the sake of an agro-industrial company would sooner or later tend to create serious social tension and conflict. There would be potential risk to emerge, and that might create serious socio-economic problem, such as once in early Rusia being critically 
anticipated by Chayanov (1920; in Thorner, D. 1966); in that it might trigger a negative situation, and herewith to be called as Chayanov's syndrome. It is therefore a worthwhile socio-economic study that could distil any lesson learned out of a 'success story' as experienced by PT BAP which has been envied by surrounding people who also need plots of land for livelihood.

The Identified Problem \& Importance of the Study. The classic phenomenon about livelihood competition among small-holders farming community against large scale (rich \& borguise) farmers had been known in the literature ever since a publication of manuscript on this issue by Chayanov (1923) of Rusia. The issue is actually still relevant even in this 21 st century agribusiness era, as Thorner, D (1966) considered the Chayanov theoretical view so important as he intentionally translated the classic writing under an English title of "The Theory of Non-Capitalist Economic System". Truly speaking, what had become concern of Chayanov during pre-communist era in Rusia has also become serious matter within economic life of modern Indonesia. As clearly implied by the enactment of in Act \#23/1997 (On Environmental Policy; in which CSR is voluntary) as well as Act \#25/2007 and At \#40/2007 (specific law for State Owned Business Corporation and Private Owned Business Corporation respectively; in which CSR is stated mandatory) the application of CSR policy has got the same spirit as known in the west (c.f. Kolefa, P. et.al. 2014; Fontaine, M.2013).

Given the fact that PT-BAP company's concession is at quite a distance far from the capital city of Palembang (about 3-hours by boat), and the area typified by tidal swamp and peatland type of soil, then it could have been considered a potential agro-ecosystem of the last resort to be grasped by people. There are actually 11 big villages of small holder farmers of mostly trans-migrants (Javanese settlers located there since 1982) that leave in surrounding of the BAP's concession. The small holders activities may be considered as traditional farming without blessed by irrigation but simple drainage system, that only allows farmers to produce mainly paddy once a year or twice at the most. As the agricultural area is quite far away from the main market, then no wonder if economic prosperity of the people there has still been quite slow to get improved over time. Hence social competition to obtain land plots could still become possible venture in the future. A kind of anticipation to such problem is badly expected, and a special research to assess the company's CSR fund dedicated particularly for community development (CD) program as a case study is certainly needed.

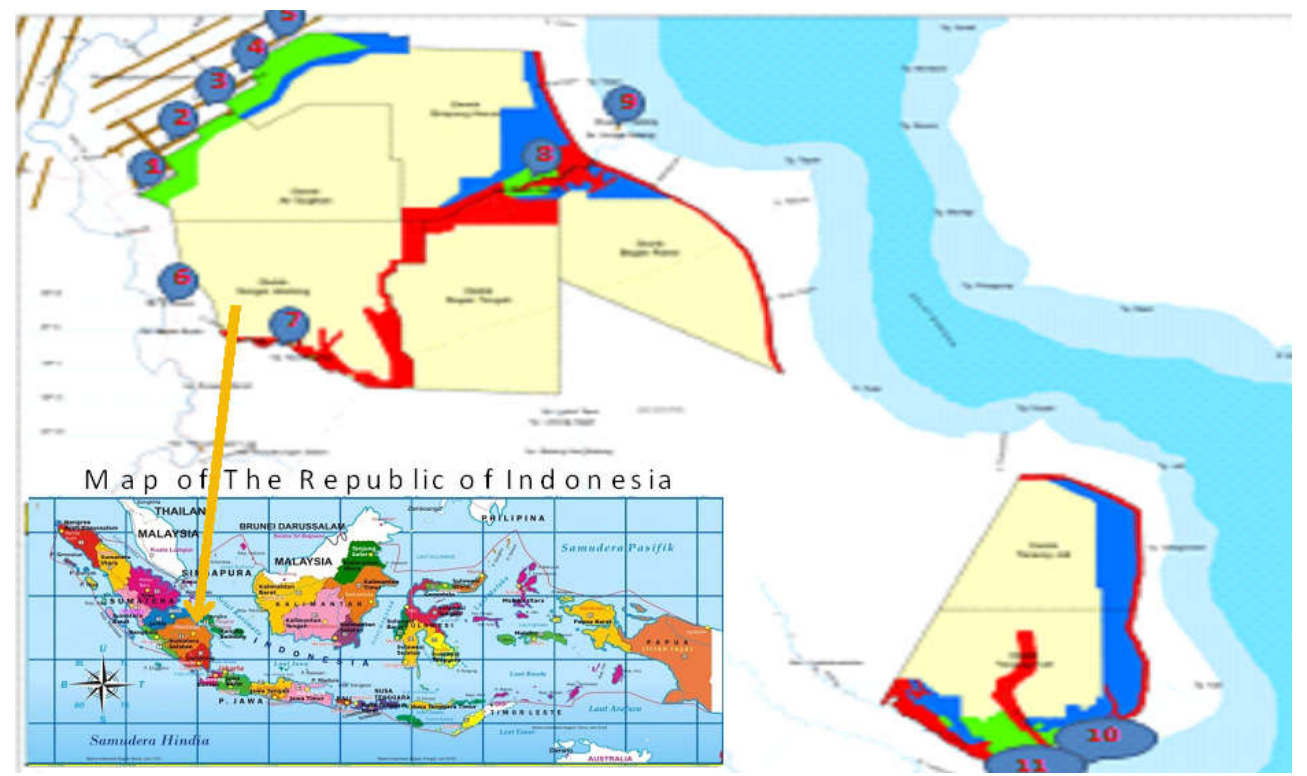

Note: The two green (dry land) and blue (wetland) areas still exist next to the 2-part of the BAP's concession are less than 39.372 HAs of reserved agro-ecosystem under control by PT-BAP, that may be accessible to group people of small farmers specially supported by CSR fund of PT-BAP.

Figure 1 - Geo-Position of The Study Area which is Near The Strait of Bangka, Sumatra 
Population Target and the Research Method. In 2015 PT-BAP started distributing its CSR fund amounted to Rp1.2 billion dedicated to 5 different rural needs, as shown in Table-1 below. In terms of CD program, the district of Simpang Heran received the largest $(36.7 \%)$ proportion. The CD money was used for helping 325 small farmers to cultivate part of the green belt (agro-ecosystem).

The farmers participant being organized into 13 CD-groups of 25 farmers each, and each person entitled to cultivate 1-HA of the reserved land area. The participant may choose to grow paddy and followed by corn (9 groups), or corn and then corn crops (by 4 groups). The participant may use the working capital of about Rp2 million/ HA as long as he wants, and he must passes the money to other person when he decides to quit from the CD program.

It was due to those reasons while also considering easiest accessibility to get to the peasant population, then Simpang Heran was chosen as the district of study. The farmer population of Simpang Heran was 590 head of families. They were mostly small farmers of paddy and other seasonal crops. Using simple random-sampling method 60 of them $(10 \%)$ were interviewed led by a set of survey questioners.

Table 1 - Total Rupiahs of CSR Fund Distriibuted by PT-BAP for Five Different Sectoral Items, 2015

\begin{tabular}{|c|c|c|c|c|c|c|c|c|c|c|c|c|}
\hline \multirow{2}{*}{ Sub-District } & \multicolumn{2}{|c|}{ Economy (CD) } & \multicolumn{2}{|c|}{ Health } & \multicolumn{2}{|c|}{ Education } & \multicolumn{2}{|c|}{ Cultural } & \multicolumn{2}{|c|}{ Infrastructure } & \multicolumn{2}{|c|}{ Total Value of CSR } \\
\hline & $\operatorname{Rp} \times 000$ & $\%$ & $\mathrm{Rp} \times 000$ & $\%$ & $\mathrm{Rp} \times 000$ & $\%$ & $\operatorname{Rp} \times 000$ & $\%$ & $\operatorname{Rp} \times 000$ & $\%$ & $\operatorname{Rp} \times 000$ & $\%$ \\
\hline SimpangHeran & $53.875,5$ & 36,7 & $4.685,7$ & 2,6 & $7.862,5$ & $3,6 \%$ & $39.350,0$ & 14,4 & $200.000,0$ & 51,2 & $305.773,7$ & 25,3 \\
\hline Air Sugihan & $50.475,0$ & 34,4 & $28.664,0$ & 15,8 & $16.550,0$ & $7,6 \%$ & $30.250,0$ & 11,1 & $90.150,0$ & 23,1 & $216.089,0$ & 17,9 \\
\hline SungaiJelutung & $22.500,0$ & 15,3 & $14.400,0$ & 7,9 & $49.400,0$ & $22,7 \%$ & $19.850,0$ & 7,3 & $35.568,0$ & 9,1 & $141.718,0$ & 11,7 \\
\hline Tjg Jati \&Kait & $20.000,0$ & 13,6 & $76.140,4$ & 41,8 & $84.400,0$ & $38,8 \%$ & $78.650,0$ & 28,8 & $65.183,8$ & 16,7 & $324.374,2$ & 26,8 \\
\hline BgnRame-Tgh & - & 0,0 & $36.975,0$ & 20,3 & $59.400,0$ & $27,3 \%$ & $21.600,0$ & 7,9 & - & 0,0 & $117.975,0$ & 9,7 \\
\hline Others & - & 0,0 & $21.105,4$ & 11,6 & - & $0,0 \%$ & $83.041,0$ & 30,4 & - & 0,0 & $104.146,4$ & 8,6 \\
\hline Total & $146.850,5$ & 2,1 & $181.970,5$ & 15,0 & $217.612,5$ & $18,0 \%$ & $272.741,0$ & 22,5 & $390.901,8$ & 32,3 & 1.210 .0 & 30 \\
\hline
\end{tabular}

Theoretical Framework and the Hypothesis. For its sustainability, each industrial forestry company has got to maintain harmonious life within its social environment. This has to be a consistent part of environmentally sound but innovative management at either its primary farm stage as well as agro-industrial stage of production.

Unfortunately, the fortune of a big agribusiness company is not always parallel with the economic fate of the small-holders or peasantry. In this particular case, the two actors cultivate their land for a different commodities, although the people nearby may get opportunity to become labourers in the concession and gain extra income. Therefore, there could be Chayanov's syndrome to play around the 2-farming actors, that have unequal power to manipulate any threat coming from either technical or economic factors ${ }^{1}$ to be influencing such farming life and the agribusiness endeavour. Failure to anticipate the problem it may become disastrous.

As being implied by the Chayanov theory on peasantry economics, the un-wanted syndrome should be tackled utilizing economic slot and momentum coming along with a propoor policy supposedly mandated (CSR) by the government. Of course the CSR fund may be available for fulfilling stakeholders' interests that exist that must be local specific to a particular district. In fact, only according to information in Table 2, only part of the CSR fund being focused on a CD program that may directly affect economic fortune of the people. Hence the following arguments may apply:

Define an average economic fortune as $\delta Y=f\left(C D_{C S R}\right)$ and $\delta Y>0$, then for those people of limited income, assuming that baseline $C_{o}=Y_{o}$ then there could be two alternative ways that each family would actually utilize $\delta Y$ for zero or an additional consumption $(\delta C)$, such that: $\left(1_{a}\right) \delta C<\delta Y \ldots$. meaning that the family may get motivated positively; $\left(1_{b}\right) \delta C=\delta Y \ldots$.

\footnotetext{
${ }^{1}$ In the case of oil palm cropping which is highly water consuming due to non-stop emergence of its fresh fruit bunch along the productive years, then a big company that has got proper drainage system tend to close its water gates in order to maintain sufficient water availability within its concession during dry season regardless the fate of the neighboring small-holders who depend their farming fortune to be blessed only by mother nature (Sjarkowi, F. 2014). By the same token, accessibility of innovative package of production management is presumably much faster and easier to a big company as compared with those small holders peasantry (Sjarkowi, F. 2017). Had there been no effort what so ever specially dedicated to the SMEs (small \&medium enterprises), then the big one may gain much faster and larger than the peasants, and social entropies may consequently emerge and tend to trigger social conflict.
} 
meaning that the family may feel hopeless; $\left(1_{c}\right) \delta C>\delta Y \ldots$. meaning that the family may get intimidated constantly.

Outcome (1a) indicate successful implementation of the CD program, and otherwise for (1b); from either one of which some determining factors may be revealed.

The financial gained by each family of the CD participants may also be seen from 3 approaches towards more prospective farming performance, namely: $\left(2_{a}\right)$ Efficiency improvement; that surely lower the average production cost; $\left(2_{b}\right)$ Effectiveness betterment; that minimize waste but maximize essential yield; $\left(2_{c}\right)$ Sustainability achievement; that save energy and other resources for future use.

These 3-best performance would uplift financial gain directly and indirectly as well. Otherwise, persistently bad farming performance may encourage people to uplift income by simply increase size of land base, hence it tends to encourage incident of land encroachment within BAP's concession and also illegal deforestation. For this particular argument it will be interesting to detect as to which decision variable that actually influence the participant to join the CD-program. A regression equation of the following structure may be assessed using cross-sectional data collected from 60 respondents:

$$
g\left(X_{i}\right)=\ln \left[F\left(X_{i}\right) / 1-p\left(X_{i}\right)\right]=b_{\circ}+\sum b_{i} X_{i} \text { for } I=1,2, \ldots, 7
$$

Where: $b_{o}=a$ constant. $b_{i}=$ the parameters, for $I=1,2, \ldots, 5 ; X_{1}=$ income; $X_{2}=$ educational back-ground; $X_{3}=$ group commitment; $X_{4}=$ hard land preparation; $X_{5}=$ land-plot size; $\mathrm{X}_{6}=$ land-plot distance far; $\mathrm{X}_{7}=$ existing water control. It was expected: $\mathrm{b}_{1}>0 ; \mathrm{b}_{2}<0 ; \mathrm{b}_{3}>0$; $b_{4}>0 ; b_{5}<0 ; b_{6}>0$, and $b_{7}<0$.

Enacting law on mandatory CSR as source of additional fund for financing various people mattered programs is supposed to be appropriate government intervention that must be taken as golden opportunity by the small holders as a peasantry group based agribusiness entity without having to get provoked by any kind of social sentiment. By so doing then the following social tendency could positively apply:

$\left(3_{a}\right)$ Small is weaken; then the peasants need to unite but institutionally manageable as a partnership business entity, without having to get provoked by external agent to trigger any socio-psychological entropy.

$\left(3_{b}\right)$ Small is beautiful (= agreeably abided by government law), then the more organized peasants may consistently adopt intensive production management without bringing with it socio-ecological entropy.

$\left(3_{c}\right)$ Small is flexible, then as formal business entity the more responsive peasantry power may easily get encouraged to innovate and capture added values, so as not to become agent of socio-economic entropy.

$\left(3_{d}\right)$ Small is risk-averter, then the peasantry group may generate trustful economic power and perform actively within an agribusiness system, and successfully free from causing any kind of socio-cultural entropy.

Of course achievement $\left(3_{\mathrm{a}}\right)$ could bring stability with it, and $\left(3_{\mathrm{b}}\right)$ could uplift productivity, and $\left(3_{c}\right)$ could give equality, while eventually $\left(3_{d}\right)$ could promote sustainability. Such group achievement is an essential element of controlling the Chayanov syndrome from coming into reality and causing social disturbance that may fail a social economic partnership deal.

\section{RESULTS OF STUDY}

Doing agricultural activity to grow food crops such as paddy, corn and also cassava in tidal swamp area and sometime characterized with peat-land is not always an easy peasantry venture. The main constraint that has to be faced in this case is water management that must tackle need for water in terms of proper QQA (quantity that cannot be fully controlled; quality that tends to be lower $\mathrm{pH}$ although being influenced to some extend by sea tide, then; availability typified by excessive water level during wet or rainy season and deficit during dry season). Growing seasonal crop at time towards the end of wet season up until the beginning of dry season could give better chance to success, which was measurable 
as positive net revenues, however small it is actually (see pre-CD performance, Table-2). Even so, the classic problems of pest and weed attack should still require serious attention for it might blow up incidental variable costs.

The role of a CD program provided by a big company, such as the capital intensive BAP-corporation that exists nearby villages, would certainly provide the peasants with much help, especially in the form of lending working capital, better technique and agronomic methods and other matters regarding marketing of the farm products. According to Table-2 above, very significant increase (nearly doubled or more) in productivity was achieved due to more intensive method of paddy crop production. In fact after harvesting paddy crops some small-holder farmers could continue its 'business' venture by growing corn, a seasonal crop that is usually more tolerant to a rather wet up to dryer condition and also saver from pest attack. By growing corn after paddy crop there could be additional income of about Rp2.0 million as net revenue obtained from around $1.500 \mathrm{Kg} / \mathrm{HA}$ of corn production on average.

Table 2 - Production \& Revenue Achievement Before and After CD Program Dedicated by The BAP Corporation as CSR Courtasy to Its Neighbouring Peasantry Families, 2016/2017

\begin{tabular}{|l|c|c|c|c|}
\hline \multirow{2}{*}{\multicolumn{1}{|c|}{ Average performance }} & \multicolumn{2}{c|}{ Trans-migrants } & \multicolumn{2}{c|}{ Local farmers } \\
\cline { 2 - 5 } & $(\mathrm{Y})$ & $\left(\mathrm{Y}^{\prime}\right)$ & $(\mathrm{Y})$ & $\left(\mathrm{Y}^{\prime}\right)$ \\
\hline Production $(\mathrm{Kg} / \mathrm{Ha})$ & 2.919 & 5.556 & 2.100 & 4.805 \\
\hline Price of paddy $(\mathrm{Rp} / \mathrm{Kg})$ & 3.600 & 3.750 & 3.600 & 3.750 \\
\hline Revenue $(\mathrm{Rp} / \mathrm{Ha})$ & 10.508 .400 & 20.835 .000 & 7.560 .000 & 18.018 .750 \\
\hline Production cost $(\mathrm{Rp} / \mathrm{Ha})$ & 8.533 .822 & 14.693 .896 & 6.898 .113 & 12.806 .167 \\
\hline Income $(\mathrm{Rp} / \mathrm{Ha})$ & 1.974 .578 & 6.141 .104 & 661.887 & 5.212 .583 \\
\hline
\end{tabular}

Notes: $(Y)=$ performance in 2014 (pre-CD program); and $\left(Y^{\prime}\right)$ performance in 2016 (ex-post CD program). During 2015 normal data could not be compared with the 2016, because of severe and prolonged dry season followed by many land and forest fire disasters happened to fail many agricultural activities at that particular year.

Clearly by having $C D$ support from the company the small farmers really get empowered, although the achievable total income from seasonal crop production had not been high enough for the peasantry families to attain a consumptive status of prosperity. Surely limited land acreage and the isolated location of the trans-migrant settlement (quite far distance from central market, and river transportation facilities depend upon high tiding) had become the main factor that constrain the people to enjoy a better living condition so far. Although each trans-migrant family obtained 2.0 Ha land plot to make a living, then the above information revealed some factual information about how hard they should be geo-physically and economically adapting alone year by year. No wonder if some of them decided to do illegal logging, and some might have to do inland water fishing and hunting while they could do those things in the middle of the bounty area controlled by rich mother-nature as previously available vastly.

Without such an empowering CD program that also allow them to utilize 1.0 HA of reserved land area within the BAP concession then the peasantry families living nearby the company with various physical and financial difficulties would sooner or later bring the people to a point of no return but to promote hostile claim to some acreages within and part of the concession area. Now they could do much better and very much more friendly to thank PTBAP, because the new way of farming could also be applied in the allocated land that they had got ever since they arrived in the 'new' settlement area. Although not enough data yet available as of now (because positive effect of the production technique experienced in the CD plots towards those originally owned land plot still need to be assessed this year) but then the hypothesis that says $\delta C<\delta Y$ as stated earlier seems to be valid and not rejected by any evident that so far obtained. There are vivid signs that give positive indication, meaning that the peasantry family really get motivated positively by the CD program.

The fact that labour intensive and traditional paddy farming could not give a better living standard to the trans-migrant and local farmers for quite so long provide clear reasons for the people to thank the BAP corporation that came quite recently but gave an opportunity for the peasants to be part of the company's CD-program, that had really been executed and successfully opened the participants mind towards a clear but peaceful progress. As clearly 
implied by information in Table-2, the paddy crop farming got improved vividly in its production efficiency and farming effectiveness as well as promising sustainability.

\begin{tabular}{|c|c|c|c|}
\hline \multirow{3}{*}{$\begin{array}{l}\text { Socio- } \\
\text { Psychological } \\
\text { Entropy }\end{array}$} & \multirow{3}{*}{$\begin{array}{l}\text { Weakness in } \\
\text { Educational } \\
\text { background }\end{array}$} & Formal & $\begin{array}{l}\text { 1.About } 65 \% \text { of the villagers got educated up to elementary school } \\
\text { 2.Although most of the active villagers aged } 25-45\end{array}$ \\
\hline & & In - Formal & $\begin{array}{l}\text { 1. About } 75 \% \text { of the villagers very rarely get innovative training on } \\
\text { farming } \\
2 \text {. Some people considered extension service lack of relevance, } \\
\text { but more promotional business oriented }\end{array}$ \\
\hline & & Non - Formal & $\begin{array}{l}\text { 1.More involvement in religious activities but lower quality in } \\
\text { substance } \\
\text { 2.Many local opportunists play their role without respecting moral } \\
\text { values }\end{array}$ \\
\hline \multirow{3}{*}{$\begin{array}{l}\text { Socio- } \\
\text { Ecological } \\
\text { Entropy }\end{array}$} & \multirow{3}{*}{$\begin{array}{l}\text { Unidentified } \\
\text { Location specific } \\
\text { Best practice }\end{array}$} & Local wisdom & $\begin{array}{l}\text { 1. To new settlers in the frontier area, it may take long time to get } \\
\text { wisdom } \\
\text { 2. To the locals old local wisdom seem to be no longer relevant }\end{array}$ \\
\hline & & Local ignorance & $\begin{array}{l}\text { 1. Tendency to get influenced by consumerism } \\
\text { 2. Lack of effort to do environmentally sound activities }\end{array}$ \\
\hline & & $\begin{array}{c}\text { Local } \\
\text { shortcoming }\end{array}$ & $\begin{array}{l}\text { 1. Influence of narcotics and liquor has penetrated villages } \\
\text { 2. incidence of robber and stealing more frequently }\end{array}$ \\
\hline \multirow{3}{*}{$\begin{array}{l}\text { Socio- } \\
\text { Economic } \\
\text { Entropy }\end{array}$} & \multirow{3}{*}{$\begin{array}{l}\text { Limited } \\
\text { Source of Local } \\
\text { Livelihood }\end{array}$} & Main source & $\begin{array}{l}\text { 1. Not all villagers get opportunity to cultivate and reserved, but; } \\
\text { 2. Convertible portion of remaining ecosystem for agricultural land } \\
\text { is getting scarce }\end{array}$ \\
\hline & & $\begin{array}{l}\text { Additional } \\
\text { sources }\end{array}$ & $\begin{array}{l}\text { 1. Villagers feel that job opportunity getting difficult to obtain. } \\
\text { 2. More job tend to require more skill while villagers generally lack } \\
\text { of skill }\end{array}$ \\
\hline & & $\begin{array}{l}\text { Expectable } \\
\text { source }\end{array}$ & $\begin{array}{l}\text { 1. Innovative and creative business activities have not yet began } \\
\text { to grow. } \\
\text { 2. Traditional ways of agricultural processing require more } \\
\text { scientific touches }\end{array}$ \\
\hline \multirow{3}{*}{$\begin{array}{l}\text { Socio- } \\
\text { Cultural Entropy }\end{array}$} & \multirow{3}{*}{$\begin{array}{l}\text { Eroding } \\
\text { Traditional Values }\end{array}$} & $\begin{array}{l}\text { Coexistence } \\
\text { values }\end{array}$ & $\begin{array}{l}\text { 1. Egoism seems to exist every where } \\
\text { 2. Easiness to agree on critical issues no longer hold, need role of } \\
\text { charismatic leader }\end{array}$ \\
\hline & & $\begin{array}{l}\text { Collaborative } \\
\text { values }\end{array}$ & $\begin{array}{l}\text { 1. Suspicious attitude happens to affect many people } \\
\text { 2. Trust worthy has been so expensive }\end{array}$ \\
\hline & & $\begin{array}{l}\text { Cooperative } \\
\text { values }\end{array}$ & $\begin{array}{l}\text { 1. Rural institution cannot hold responsibility automatically } \\
\text { 2. Among people of different villages get difficult to unite to tackle } \\
\text { risk }\end{array}$ \\
\hline
\end{tabular}

Based on production and financial achievement at the CD plots, average efficiency improvement was indicated by performance index of BCR (pre-CD) $=1.23$ becoming BCR $($ post-CD) $=1.42$ as achieved by the trans-migrant farmers, and BCR (pre-CD) $=1.10$ becoming BCR (post-CD) $=1.41$ as achieved by the local farmers. Likewise, in terms of farming effectiveness, improvement in productivity had taken place in the plots by better group decision in choosing proper time to start seedling and planting paddy crop; for which the use of available water that very much depends on blessing of mother-nature could actually match the time schedule for step by step agronomic action in the land plots. Towards the end of paddy harvesting time, the CD program had successfully recommended the group participants to grow corn by taking advantage of the available organic remnants from paddy cropping.

It is interesting also to know what other factors that trigger the CD group members to join the program. The estimated logit function as shown by Table-3 below revealed that a variable named 'group commitment' was most influential to participating decision in the CD farming activity. Meanwhile the distance far of the land plots from home seemed to be significantly influential to the people willingness to join the program, and that may to some extend indicate that a tendency to do land hunting appeared to be rather strong. This tendency must remind all parties to be constantly alert against the possibility of social disruption that may hamper stakeholder's interest to maintain sustainability of all agribusiness activities in the location.

\section{CONCLUSION}

The CSR program launched by PT-BAP has so far been warmly accepted by the targeted people; although not much significant achievement in terms of additional income. 
Several technical constraints and social hindrances apparently still existed, against which some strategic improvement in extension service and innovative business process must be introduced.

There were several evident that might become unintended seeds of social entropy (psychological, ecological, economic and cultural entropies). Should they get triggered to grow, then social disputes might emerge to allow the 'Chayanov syndrome' to come into reality. Hence a better content of CD-program should be conducted by PT-BAP with more institutionalized way.

\section{REFERENCES}

1. Chayanov, A.V. 1966. The Theory of Peasant Economy (Edited by Daniel Thorner, Basile Kerblay and R.E.F. Smith). Illinois: Homewood.

2. Fontaine, M. 2013. Corporate Social Responsibility and Sustainability: The New Bottom Line?. International Journal of Bussiness and Social Science. National Louis University : USA. Vol 4 No 4 April 2013.

3. Koleva, P, et.al. 2014. Corporate Social Responsibility in An International Perspective: Europe, Russia, and Tunisia ; An Introduction. EAST-WEST Journal of Economics and Business Vol. XVII - No.1. 2014.

4. Fatika, M. Sitepu. 2016. Faktor Pendukung Dan Penghambat Kemitraan Sosial Dalam Pengelolaan Tanaman Kehidupan di Kawasan Hutan Tanaman Industri PT. Bumi Andalas Permai (Kasus: Desa Simpang Heran). Tesis Magister Agribisnis Fakultas Pertanian Universitas Sriwijaya. Inderalaya. Unpublished MSi Thesis.

5. Pedace, R.2013. Econometrics For Dummies A Wilet Brand. Associate Professor in The Departement Of Economics, Scripps Colagge. United States of America ISBN 978- 1 $118-53391-8$ (ebk) ; ISBN $978-1-1118-53384-0$ (pbk) Library of Congress Control Number : 2013934761.

6. Sjarkowi, F. 2014. Agro-Ekosistem \& Ekosistem Lahan Basah Lestari; Penopang Kedaulatan Pangan dan Kemakmuran NKRI. 429pp. CV Baldad Grafiti Press, Palembang.

7. Sjarkowi, F. 2016. Socio-Entropic Controlling Interface (SECl) in A Planned Social Agroforestry: An Emphirical Contribution to The Theory of Social Partnership; A Journal paper. Forth coming. 